ISSN 1112-9867

Available online at http://www.jfas.info

\title{
EFFECT OF POPULATION DENSITY AND DOSE OF NITROGEN AND POTASSIUM FERTILIZERS ON PERFORMANCE OF GREEN BEAN (PHASEOLUS VULGARIS)
}

\author{
A. Hussein ${ }^{1, *}$, M. Benmoussa ${ }^{1}$, M. Abbad ${ }^{2}$ \\ ${ }^{1}$ Department of Biotechnology, Faculty of Nature and life sciences, University of Blida-1, \\ Algeria \\ ${ }^{2}$ Department of Horticulture, Faculty of Agriculture and Natural Resources, University of \\ Kassala, Sudan
}

Received: 14 March 2017 / Accepted: 25 November 2017 / Published online: 01 January 2018

\begin{abstract}
This experiment was executed in a split randomized complete block design with three replications. Two plant densities (D), $\left(\mathrm{D}_{1} ; \mathrm{D}_{2}\right)$ equal to one plant and two plants per pot and seven fertilizers doses (F), $\left(\mathrm{N}_{0} \mathrm{~K}_{0} ; \mathrm{N}_{1} \mathrm{~K} 0 ; \mathrm{N}_{1} \mathrm{~K}_{1} ; \mathrm{N}_{2} \mathrm{~K}_{0} ; \mathrm{N}_{2} \mathrm{~K}_{2} ; \mathrm{N}_{0} \mathrm{~K}_{1} ; \mathrm{N}_{0} \mathrm{~K}_{2}\right)$ were investigated. $\mathrm{N}_{0}, \mathrm{~N}_{1}$ and $\mathrm{N}_{2}$ equal to $0,0.46$, and $0.92 \mathrm{~g}$ urea while, $\mathrm{K}_{0}, \mathrm{~K}_{1}$ and $\mathrm{K}_{2}$ equal to 0 , 0.42 and $0.84 \mathrm{~g}$ potassium sulfate, respectively. The results showed that the treatments had no effect on the number of branches per plant and vice versa the interaction. Lower plant density $\left(D_{1}\right)$ and higher dose of both elements $\left(\mathrm{N}_{2} \mathrm{~K}_{2}\right)$ significantly increased shoots dry weight, number of pods and pod yield per plant while, in second season the higher value of those yield parameters was obtained at lower dose of nitrogen $\left(\mathrm{N}_{1} \mathrm{~K}_{0}\right)$, the interaction of those treatments increased significantly plant dry weight. The interaction between lower plant density $\left(D_{1}\right)$ and nitrogen irrespective of their quantity and potassium, $\left(\mathrm{N}_{1} \mathrm{~K}_{0} ; \mathrm{N}_{1} \mathrm{~K}_{1} ; \mathrm{N}_{2} \mathrm{~K}_{0}\right.$ and $\mathrm{N}_{2} \mathrm{~K}_{2}$ ) increased the number of pods and pods yield per plant, while the greatest yield per hectare was obtained at density planting $\left(D_{2}\right)$ receiving higher doses of both fertilizer and lower dose of nitrogen $\left(\mathrm{N}_{2} \mathrm{~K}_{2}: \mathrm{N}_{1} \mathrm{~K}_{0}\right)$ at the first and second season respectively.
\end{abstract}

Keywords: Cultivar Djadida; Nutrient Competition; Vegetative Productivity.

Author Correspondence, e-mail: abdallamohussein@gmail.com

doi: http://dx.doi.org/10.4314/jfas.v10i1.4 


\section{INTRODUCTION}

Green beans are dicotyledonous plants forming part of the species (Phaseolus vulgaris L.). According to Monfreda et al., (2008) estimate for the year 2006, the world beans production was $1235 \mathrm{~kg} \mathrm{ha}^{-1}$ while, that of Africa was $799 \mathrm{~kg} \mathrm{ha}^{-1}$. These low yields are pronounced in grain legumes and are often associated with declining soil fertility due to biological and environmental factors (Mfilinge et al., 2014). Nitrogen is one of the most limiting nutrients to plant growth (Hirel et al., 2007). Potassium improved fruit quality (Beg and Sohrab, 2012) while, nitrogen consumption increased dry weight resulting in increased plant yield (Hatami et al., 2009). Vorob (2000) recorded positive effect of potassium application at all proportions on growth and yield of peas. Lower density had the heaviest shoot dry weights (Elhag and Hussein, 2014) and the highest number of pods per plant (Mtaita and Mutetwa, 2014). Low crop productivity and quality are a general phenomenon facing most producers. The objective of this study was to investigate the effect of plant density and dose of nitrogen and potassium on Green bean Cv. Djadida.

\section{MATERIALS AND METHODS}

\section{1. Site of Experiment}

This study was carried out during winter seasons of the years 2015 and 2016 in glasshouse of laboratory of vegetables production, faculty of Nature and Life Sciences, University of Blida1, Algeria. The geographical coordinates are $36^{\circ} 28^{\prime} 7^{\prime \prime}$ North, $2^{\circ} 49^{\prime} 44^{\prime \prime}$ East, $260 \mathrm{~m}$ above sea level.

\subsection{Experimental Design}

The experiment was executed in split trial in randomized complete block design with three replications. Four plastic pots $33 \times 30 \mathrm{~cm}$ in dimensions contain $8.5 \mathrm{Kg}$ soil were used as an experimental units.

\section{3. Treatments}

The treatment consisted of two plant densities (D), $\left(D_{1}\right)$ one plant per pot (107145 plants per hectare) and two plants per pot $\mathrm{D}_{2}$ (214290 plants per hectare) used as main plot, and seven fertilizers doses (F), $\left(\mathrm{N}_{0} \mathrm{~K}_{0} ; \mathrm{N}_{1} \mathrm{~K}_{0} ; \mathrm{N}_{1} \mathrm{~K}_{1} ; \mathrm{N}_{2} \mathrm{~K}_{0} ; \mathrm{N}_{2} \mathrm{~K}_{2} ; \mathrm{N}_{0} \mathrm{~K}_{1}\right.$; and $\left.\mathrm{N}_{0} \mathrm{~K}_{2}\right)$ used as sub plot. $\mathrm{N}_{0}, \mathrm{~N}_{1}$ and $\mathrm{N}_{2}$ equal to $0,0.46$, and $0.92 \mathrm{~g}$ urea (46\% nitrogen) per pot respectively, while $\mathrm{K}_{0}$, $\mathrm{K}_{1}$ and $\mathrm{K}_{2}$ equal to $0,0.42$ and $0.84 \mathrm{~g}$ potassium sulfate (50\% potassium) per pot respectively.

\section{4. Soil characteristics}

The soil is heavy clay with $\mathrm{pH} 7.75$, and electric conductivity of $0.49 \mathrm{ds} \mathrm{m}^{-1}$, contained 0.002 
Meg $\mathrm{g}^{-1}$ potassium sulfate, $0.8 \mathrm{~g} \mathrm{Kg}^{-1}$ azotes and $1.80 \%$ organic matter.

\subsection{Sowing}

The seeds were soaked in water for one day and pre-sown in a moist piece for four days, and then transplanted. The fertilizers treatment applied as one dose, four weeks from sowing.

\subsection{Data Collection}

The data of both seasons was recorded (40 days from sowing) to evaluate the effect of treatments on the number of branches per plant, shoot dry weight, number of pods per plant, pod fresh weight, pod yield per plant and pod yield per hectare.

\subsection{Statistical Analyses}

The data was statistically analyzed using computer software programme (MSTAT-C). Randomized Complete Block Design (R. C. B. D) was applied for data analysis and Duncan multiple range test D. M. R. T, was used for mean separation.

\section{RESULTS}

\subsection{Number of branches per plant}

No significant effect was noticed in both seasons on the number of branches per plant due to the plant density or due to nitrogen and potassium fertilizer (Table 1). Number of branches per plant was significantly affected by plant density and nitrogen and potassium interaction. A single plant per pot $\left(D_{1}\right)$ treated with lower doses of nitrogen without potassium $\left(N_{1} K_{0}\right)$ in the first season screened a superior number of branches per plant which was positively different from all other treatments and significantly for higher plant density $\left(D_{2}\right)$ receiving a high dose of potassium without nitrogen $\left(\mathrm{N}_{0} \mathrm{~K}_{2}\right)$ contrary, this treatment decreased the number of branches per plant in the second season. Single plant per pot $\left(D_{1}\right)$ receiving nitrogen at higher dose $\left(\mathrm{N}_{2} \mathrm{~K}_{0}\right)$ and two plants per pot $\left(\mathrm{D}_{2}\right)$ received no fertilizer or receiving potassium at higher dose $\left(\mathrm{N}_{0} \mathrm{~K}_{0} ; \mathrm{N}_{0} \mathrm{~K}_{2}\right)$ was statistically similar and had the highest number of branches per plant. 
Table 1. Effect of plant density and dose of nitrogen and potassium on number of branches per plant

\begin{tabular}{|c|c|c|c|c|c|c|c|}
\hline \multirow{2}{*}{\multicolumn{2}{|c|}{$\begin{array}{c}\text { Fertilizer } \\
\text { doses }\end{array}$}} & \multicolumn{2}{|c|}{ First season } & \multirow[b]{2}{*}{ Mean } & \multicolumn{2}{|c|}{ Second season } & \multirow[b]{2}{*}{ Mean } \\
\hline & & \multirow{2}{*}{$\begin{array}{c}1 \text { plant/pot } \\
6.00^{\mathrm{ab}}\end{array}$} & \multirow{2}{*}{$\begin{array}{c}2 \text { plants/pot } \\
6.42^{\mathrm{ab}}\end{array}$} & & \multirow{2}{*}{$\begin{array}{c}1 \text { plant/pot } \\
5.75^{\mathrm{ab}}\end{array}$} & \multirow{2}{*}{$\begin{array}{c}2 \text { plants/pot } \\
6.17^{\mathrm{a}}\end{array}$} & \\
\hline $\mathrm{N}_{0}$ & $\mathrm{~K}_{0}$ & & & $6.21^{\mathrm{a}}$ & & & $6.69^{\mathrm{a}}$ \\
\hline $\mathrm{N}_{1}$ & $\mathrm{~K}_{0}$ & $6.72^{\mathrm{a}}$ & $6.33^{\mathrm{ab}}$ & $6.53^{\mathrm{a}}$ & $4.83^{b}$ & $6.00^{\mathrm{ab}}$ & $5.42^{\mathrm{a}}$ \\
\hline $\mathrm{N}_{1}$ & $\mathrm{~K}_{1}$ & $6.17^{\mathrm{ab}}$ & $6.33^{\mathrm{ab}}$ & $6.25^{\mathrm{a}}$ & $5.53^{\mathrm{ab}}$ & $5.50^{\mathrm{ab}}$ & $5.51^{\mathrm{a}}$ \\
\hline $\mathrm{N}_{2}$ & $\mathrm{~K}_{0}$ & $6.67^{\mathrm{ab}}$ & $6.33^{\mathrm{ab}}$ & $6.50^{\mathrm{a}}$ & $6.19^{a}$ & $5.61^{\mathrm{ab}}$ & $5.90^{\mathrm{a}}$ \\
\hline $\mathrm{N}_{2}$ & $\mathrm{~K}_{2}$ & $6.56^{\mathrm{ab}}$ & $6.50^{\mathrm{ab}}$ & $6.53^{\mathrm{a}}$ & $5.78^{\mathrm{ab}}$ & $5.53^{\mathrm{ab}}$ & $5.65^{\mathrm{a}}$ \\
\hline $\mathrm{N}_{0}$ & $\mathrm{~K}_{1}$ & $6.17^{\mathrm{ab}}$ & $6.42^{\mathrm{ab}}$ & $6.29^{\mathrm{a}}$ & $5.83^{\mathrm{ab}}$ & $5.67^{\mathrm{ab}}$ & $5.75^{\mathrm{a}}$ \\
\hline $\mathrm{N}_{0}$ & $\mathrm{~K}_{2}$ & $6.25^{\mathrm{ab}}$ & $5.67^{\mathrm{b}}$ & $5.96^{\mathrm{a}}$ & $6.00^{\mathrm{ab}}$ & $6.25^{\mathrm{a}}$ & $6.13^{\mathrm{a}}$ \\
\hline \multicolumn{2}{|c|}{ Mean } & $6.36^{\mathrm{a}}$ & $6.29^{\mathrm{a}}$ & & $5.70^{\mathrm{a}}$ & $5.82^{\mathrm{a}}$ & \\
\hline \multicolumn{2}{|c|}{ LSD at 0.05} & D 0.94 & F 0.75 & DF 0.89 & D 1.44 & F 0.912 & DF 1.9 \\
\hline C V\% & & & & 8.39 & & & 11.22 \\
\hline
\end{tabular}

Differences between means as indicated by the same letters for the different treatments are not statistically significant at probability $\leqslant 0.05$.

\subsection{Shoot dry weight (g)}

As in Table 2 Plant density, fertilizer doses and their interaction had a significant effect on plant dry weight. Increasing plant density up to two plants per pot $\left(D_{2}\right)$ decreased significantly plant dry weight, compared with lower plant density $\left(D_{1}\right)$. The higher dose of nitrogen and potassium $\left(\mathrm{N}_{2} \mathrm{~K}_{2}\right)$ in both seasons and lower dose of nitrogen without potassium in the second season $\left(\mathrm{N}_{1} \mathrm{~K}_{0}\right)$ gave the greatest dry weights of the plant. Lower and higher dose of potassium without nitrogen $\left(\mathrm{N}_{0} \mathrm{~K}_{1}\right.$ and $\left.\mathrm{N}_{0} \mathrm{~K}_{2}\right)$ and plant receiving no fertilizer $\left(\mathrm{N}_{0} \mathrm{~K}_{0}\right)$ decreased plant dry weight. In both seasons, lower plant density $\left(\mathrm{D}_{1}\right)$ treated with higher doses of nitrogen and potassium $\left(\mathrm{N}_{2} \mathrm{~K}_{2}\right)$ and lower dose of nitrogen $\left(\mathrm{N}_{1} \mathrm{~K}_{0}\right)$ were significantly higher in dry weight. Higher plant density $\left(D_{2}\right)$ receiving potassium without 
nitrogen of higher or lower dose $\left(\mathrm{N}_{0} \mathrm{~K}_{1} ; \mathrm{N}_{0} \mathrm{~K}_{2}\right)$ was mild in weight.

Table 2. Effect of plant density and dose of nitrogen and potassium on shoot dry weight $(\mathrm{g})$

\begin{tabular}{|c|c|c|c|c|c|c|c|}
\hline \multirow{3}{*}{\multicolumn{2}{|c|}{$\begin{array}{c}\text { Fertilizer } \\
\text { doses }\end{array}$}} & \multirow{2}{*}{\multicolumn{2}{|c|}{ First season }} & \multicolumn{4}{|c|}{ Second season } \\
\hline & & & & \multirow{2}{*}{ Mean } & & & \multirow[t]{2}{*}{ Mean } \\
\hline & & 1 plant/pot & 2 plants/pot & & \multirow{2}{*}{$\begin{array}{c}1 \text { plant/pot } \\
26.26^{\mathrm{b}}\end{array}$} & \multirow{2}{*}{$\begin{array}{c}2 \text { plants/pot } \\
14.59^{\text {def }}\end{array}$} & \\
\hline $\mathrm{N}_{0}$ & $\mathrm{~K}_{0}$ & $22.04^{\mathrm{abc}}$ & $16.60^{\text {def }}$ & $19.32^{\mathrm{abc}}$ & & & $20.42^{\mathrm{bc}}$ \\
\hline $\mathrm{N}_{1}$ & $\mathrm{~K}_{0}$ & $25.97^{\mathrm{a}}$ & $16.14^{\mathrm{ef}}$ & $21.06^{\mathrm{ab}}$ & $29.82^{\mathrm{a}}$ & $16.78^{\mathrm{de}}$ & $23.30^{\mathrm{a}}$ \\
\hline $\mathrm{N}_{1}$ & $\mathrm{~K}_{1}$ & $20.48^{\mathrm{bcd}}$ & $14.65^{\mathrm{fg}}$ & $17.57^{\mathrm{cd}}$ & $21.46^{\mathrm{c}}$ & $17.85^{\mathrm{d}}$ & $19.66^{\mathrm{bc}}$ \\
\hline $\mathrm{N}_{2}$ & $\mathrm{~K}_{0}$ & $23.71^{\mathrm{ab}}$ & $14.73^{\mathrm{fg}}$ & $19.22^{\mathrm{abcd}}$ & $26.60^{\mathrm{b}}$ & $16.94^{\mathrm{de}}$ & $21.77^{\mathrm{ab}}$ \\
\hline $\mathrm{N}_{2}$ & $\mathrm{~K}_{2}$ & $25.59^{\mathrm{a}}$ & $19.17^{\text {cde }}$ & $22.38^{\mathrm{a}}$ & $30.35^{\mathrm{a}}$ & $17.85^{\mathrm{d}}$ & $24.12^{\mathrm{a}}$ \\
\hline $\mathrm{N}_{0}$ & $\mathrm{~K}_{1}$ & $21.01^{\mathrm{bc}}$ & $10.91^{\mathrm{g}}$ & $15.96^{\mathrm{d}}$ & $23.59^{b c}$ & $14.13^{\mathrm{ef}}$ & $18.86^{\mathrm{c}}$ \\
\hline $\mathrm{N}_{0}$ & $\mathrm{~K}_{2}$ & $23.16^{\mathrm{abc}}$ & $12.78^{\mathrm{fg}}$ & $17.97^{\mathrm{bcd}}$ & $23.81^{b c}$ & $12.97^{\mathrm{f}}$ & $18.39^{c}$ \\
\hline \multicolumn{2}{|c|}{ Mean } & $23.14^{\mathrm{a}}$ & $15.00^{b}$ & & $26.00^{\mathrm{a}}$ & $15.86^{\mathrm{b}}$ & \\
\hline \multicolumn{2}{|c|}{ LSD at 0.05} & D 4.94 & F 3.11 & DF 3.71 & D 1.13 & F 3.12 & DF 2.61 \\
\hline \multicolumn{2}{|c|}{$\mathrm{C} \mathrm{V} \%$} & & & 11.54 & & & 8.84 \\
\hline
\end{tabular}

Differences between means as indicated by the same letters for the different treatments are not statistically significant at probability $\leqslant 0.05$.

\subsection{Number of pods per plant}

There were significant differences on number of pods per plant due to plant density, fertilizer and their interaction (Table 3$)$. Lower plant density $\left(\mathrm{D}_{1}\right)$ gave the maximum number of pods per plant compared with the higher plant density $\left(D_{2}\right)$. During the first season, the greatest number of pods per plant was obtained by plant treated with the highest dose of both elements $\left(\mathrm{N}_{2} \mathrm{~K}_{2}\right)$ while, the lower dose of nitrogen with potassium or without potassium $\left(\mathrm{N}_{1} \mathrm{~K}_{1} ; \mathrm{N}_{1} \mathrm{~K}_{0}\right)$ gave the highest number of pods per plant in the second season, the pair doses were statistically similar. A similar results in both seasons were presented when lower plant density $\left(D_{1}\right)$ treated with high doses of fertilizer $\left(\mathrm{N}_{2} \mathrm{~K}_{2}\right)$ in the first season and $\left(\mathrm{N}_{1} \mathrm{~K}_{1} ; \mathrm{N}_{1} \mathrm{~K}_{0}\right)$ in the 
second season. Less number of pods per plant was a base phenomenon of higher plant density $\left(D_{2}\right)$ overall fertilizer treatments compared with lower plant density $\left(D_{1}\right)$ which received the same dose of fertilizer or other dose.

Table 3. Effect of plant density and dose nitrogen and potassium on number of pods per plant

\begin{tabular}{|c|c|c|c|c|c|c|c|}
\hline \multirow{3}{*}{\multicolumn{2}{|c|}{$\begin{array}{c}\text { Fertilizer } \\
\text { doses }\end{array}$}} & \multirow{2}{*}{\multicolumn{2}{|c|}{ First season }} & \multicolumn{4}{|c|}{ Second season } \\
\hline & & & & \multirow{3}{*}{$\begin{array}{l}\text { Mean } \\
26.88^{b}\end{array}$} & \multirow{3}{*}{$\begin{array}{c}1 \text { plant/pot } \\
28.61^{\mathrm{bc}}\end{array}$} & \multirow{3}{*}{$\begin{array}{c}2 \text { plants/pot } \\
19.14^{\mathrm{e}}\end{array}$} & \multirow{3}{*}{$\begin{array}{l}\text { Mean } \\
23.88^{\mathrm{c}}\end{array}$} \\
\hline & & \multirow{2}{*}{$\begin{array}{c}1 \text { plant/pot } \\
31.84^{\mathrm{b}}\end{array}$} & \multirow{2}{*}{$\begin{array}{c}2 \text { plants/pot } \\
21.92^{\mathrm{cd}}\end{array}$} & & & & \\
\hline $\mathrm{N}_{0}$ & $\mathrm{~K}_{0}$ & & & & & & \\
\hline $\mathrm{N}_{1}$ & $\mathrm{~K}_{0}$ & $34.72^{\mathrm{ab}}$ & $23.78^{\mathrm{cd}}$ & $29.25^{\mathrm{ab}}$ & $32.38^{\mathrm{a}}$ & $23.00^{\mathrm{d}}$ & $27.69^{\mathrm{a}}$ \\
\hline $\mathrm{N}_{1}$ & $\mathrm{~K}_{1}$ & $35.80^{\mathrm{ab}}$ & $24.11^{\mathrm{cd}}$ & $29.96^{\mathrm{ab}}$ & $32.38^{\mathrm{a}}$ & $22.88^{\mathrm{d}}$ & $27.62^{\mathrm{a}}$ \\
\hline $\mathrm{N}_{2}$ & $\mathrm{~K}_{0}$ & $35.89^{\mathrm{ab}}$ & $21.43^{\mathrm{cd}}$ & $28.66^{\mathrm{b}}$ & $32.25^{\mathrm{a}}$ & $20.92^{\mathrm{de}}$ & $26.58^{\mathrm{ab}}$ \\
\hline $\mathrm{N}_{2}$ & $\mathrm{~K}_{2}$ & $38.96^{\mathrm{a}}$ & $26.00^{\mathrm{c}}$ & $32.48^{\mathrm{a}}$ & $30.75^{\mathrm{ab}}$ & $21.75^{\mathrm{de}}$ & $26.25^{\mathrm{ab}}$ \\
\hline $\mathrm{N}_{0}$ & $\mathrm{~K}_{1}$ & $32.04^{\mathrm{b}}$ & $21.50^{\mathrm{cd}}$ & $26.77^{\mathrm{b}}$ & $30.25^{\mathrm{abc}}$ & $19.38^{\mathrm{e}}$ & $24.81 b^{c}$ \\
\hline $\mathrm{N}_{0}$ & $\mathrm{~K}_{2}$ & $32.92^{\mathrm{b}}$ & $21.25^{\mathrm{d}}$ & $27.08^{\mathrm{b}}$ & $27.74^{\mathrm{c}}$ & $19.50^{\mathrm{e}}$ & $23.62^{c}$ \\
\hline \multicolumn{2}{|c|}{ Mean } & $34.59^{\mathrm{a}}$ & $22.86^{\mathrm{b}}$ & & $162.7^{\mathrm{a}}$ & $20.94^{b}$ & \\
\hline \multirow{2}{*}{\multicolumn{2}{|c|}{ LSD at 0.05}} & \multirow{2}{*}{ D 3.57} & \multirow{2}{*}{ F 3.50} & $\mathrm{DF}$ & \multirow{2}{*}{ D 1.52} & \multirow{2}{*}{ F 2.12} & DF \\
\hline & & & & 4.18 & & & 2.53 \\
\hline \multicolumn{2}{|c|}{ C V\% } & & & 8.63 & & & 5.81 \\
\hline
\end{tabular}

Differences between means as indicated by the same letters for the different treatments are not statistically significant at probability $\leqslant 0.05$.

\subsection{Pod fresh weight (g)}

Table 4 shows that pod fresh weight was not affected by different plant density nor with different doses of nitrogen and potassium fertilizers. The interaction between plant density and fertilizer doses varied significantly with a variation of plant density and fertilizer doses in the first season. In the first season, the individual plant per pot $\left(\mathrm{D}_{1}\right)$ with application of high rate of potassium without nitrogen $\left(\mathrm{N}_{0} \mathrm{~K}_{2}\right)$ was superior to the other plants in term of pod 
fresh weight, especially with a dense planting $\left(D_{2}\right)$ that received higher doses of nitrogen and $\operatorname{potassium}\left(\mathrm{N}_{2} \mathrm{~K}_{2}\right)$.

Table 4. Effect of plant density and dose of nitrogen and potassium on pod fresh weight (g)

\begin{tabular}{|c|c|c|c|c|c|c|c|}
\hline \multirow{2}{*}{\multicolumn{2}{|c|}{$\begin{array}{c}\text { Fertilizer } \\
\text { doses }\end{array}$}} & \multicolumn{2}{|c|}{ First season } & \multirow{3}{*}{$\begin{array}{l}\text { Mean } \\
5.13 \mathrm{a}\end{array}$} & \multicolumn{2}{|c|}{ Second season } & \multirow{3}{*}{$\begin{array}{l}\text { Mean } \\
5.21 \mathrm{a}\end{array}$} \\
\hline & & \multirow{2}{*}{$\begin{array}{c}\text { plant/pot } \\
5.23 \mathrm{ab}\end{array}$} & \multirow{2}{*}{$\begin{array}{c}2 \text { plants/pot } \\
5.04 \mathrm{ab}\end{array}$} & & \multirow{2}{*}{$\begin{array}{c}\text { plant/pot } \\
5.18 \mathrm{a}\end{array}$} & \multirow{2}{*}{$\begin{array}{c}2 \text { plants/pot } \\
5.30 \mathrm{a}\end{array}$} & \\
\hline $\mathrm{N}_{0}$ & $\mathrm{~K}_{0}$ & & & & & & \\
\hline $\mathrm{N}_{1}$ & $\mathrm{~K}_{0}$ & $5.32^{\mathrm{ab}}$ & $5.29^{\mathrm{ab}}$ & $5.31^{\mathrm{a}}$ & $5.58^{\mathrm{a}}$ & $5.37^{\mathrm{a}}$ & $5.48^{\mathrm{a}}$ \\
\hline $\mathrm{N}_{1}$ & $\mathrm{~K}_{1}$ & $5.41^{\mathrm{ab}}$ & $5.12^{\mathrm{ab}}$ & $5.26^{\mathrm{a}}$ & $5.45^{\mathrm{a}}$ & $5.21^{\mathrm{a}}$ & $5.33^{\mathrm{a}}$ \\
\hline $\mathrm{N}_{2}$ & $\mathrm{~K}_{0}$ & $4.97^{\mathrm{ab}}$ & $5.23^{\mathrm{ab}}$ & $5.10^{\mathrm{a}}$ & $5.10^{\mathrm{a}}$ & $5.10^{\mathrm{a}}$ & $5.10^{\mathrm{a}}$ \\
\hline $\mathrm{N}_{2}$ & $\mathrm{~K}_{2}$ & $5.48^{\mathrm{ab}}$ & $4.95^{\mathrm{b}}$ & $5.21^{\mathrm{a}}$ & $5.18^{\mathrm{a}}$ & $5.46^{\mathrm{a}}$ & $5.32^{\mathrm{a}}$ \\
\hline $\mathrm{N}_{0}$ & $\mathrm{~K}_{1}$ & $5.29^{\mathrm{ab}}$ & $5.57^{\mathrm{ab}}$ & $5.43^{\mathrm{a}}$ & $5.47^{\mathrm{a}}$ & $5.02^{\mathrm{a}}$ & $5.25^{\mathrm{a}}$ \\
\hline $\mathrm{N}_{0}$ & $\mathrm{~K}_{2}$ & $5.74^{\mathrm{a}}$ & $5.21^{\mathrm{ab}}$ & $5.47^{\mathrm{a}}$ & $5.25^{\mathrm{a}}$ & $5.04^{\mathrm{a}}$ & $5.15^{\mathrm{a}}$ \\
\hline \multicolumn{2}{|c|}{ Mean } & $5.35^{\mathrm{a}}$ & $5.20^{\mathrm{a}}$ & & $5.30^{\mathrm{a}}$ & $5.21^{\mathrm{a}}$ & \\
\hline \multicolumn{2}{|c|}{ LSD at 0.05} & D 0.17 & F 0.55 & DF 0.66 & D 0.23 & F 0.44 & $\begin{array}{l}\text { DF } \\
0.53\end{array}$ \\
\hline \multicolumn{2}{|c|}{ C V\% } & & & 7.39 & & & 5.98 \\
\hline
\end{tabular}

Differences between means as indicated by the same letters for the different treatments are not statistically significant at probability $\leqslant 0.05$.

\subsection{Pod yield per plant (g)}

The data pooled in Table 5 indicated that the plant yield responded significantly to the plant density (D), different doses of nitrogen $(\mathrm{N})$ and potassium $(\mathrm{K})$ fertilizer and their interaction. Lower plant density $\left(D_{1}\right)$ enhances pods yield per plant than the higher plant density $\left(D_{2}\right)$. In the first season higher doses of both fertilizer $\left(\mathrm{N}_{2} \mathrm{~K}_{2}\right)$ increased pod yield per plant significantly, while in the second season the half dose of nitrogen without potassium $\left(\mathrm{N}_{1} \mathrm{~K}_{0}\right)$ gave a superior yield of pods per plant followed by a plant which received a similar dose of 
nitrogen with a half dose of potassium $\left(\mathrm{N}_{1} \mathrm{~K}_{1}\right)$ in both seasons. Pod yield declined when received no fertilizer $\left(\mathrm{N}_{0} \mathrm{~K}_{0}\right)$ and when receiving potassium without nitrogen at higher dose $\left(\mathrm{N}_{0} \mathrm{~K}_{2}\right)$. Interaction between plant density and fertilizer showed that the lower plant density $\left(D_{1}\right)$ improved plant yield under all different fertilizer doses compared with the higher plant density, whereas the lower plant density $\left(\mathrm{D}_{1}\right)$ with a complete dose of nitrogen and potassium $\left(\mathrm{N}_{2} \mathrm{~K}_{2}\right)$ in the first season and half dose of nitrogen without potassium $\left(\mathrm{N}_{1} \mathrm{~K}_{0}\right)$ and half dose of both $\left(\mathrm{N}_{1} \mathrm{~K}_{1}\right)$ in the second season increased plant yield. High plant population $\left(\mathrm{D}_{2}\right)$ treated with higher potassium dose $\left(\mathrm{N}_{0} \mathrm{~K}_{2}\right)$ had a negative effect on pod yield followed by a similar density that received no fertilizer dose $\left(\mathrm{N}_{0} \mathrm{~K}_{0}\right)$.

Table 5. Effect of plant density and dose nitrogen and potassium on pod yield per plant (g)

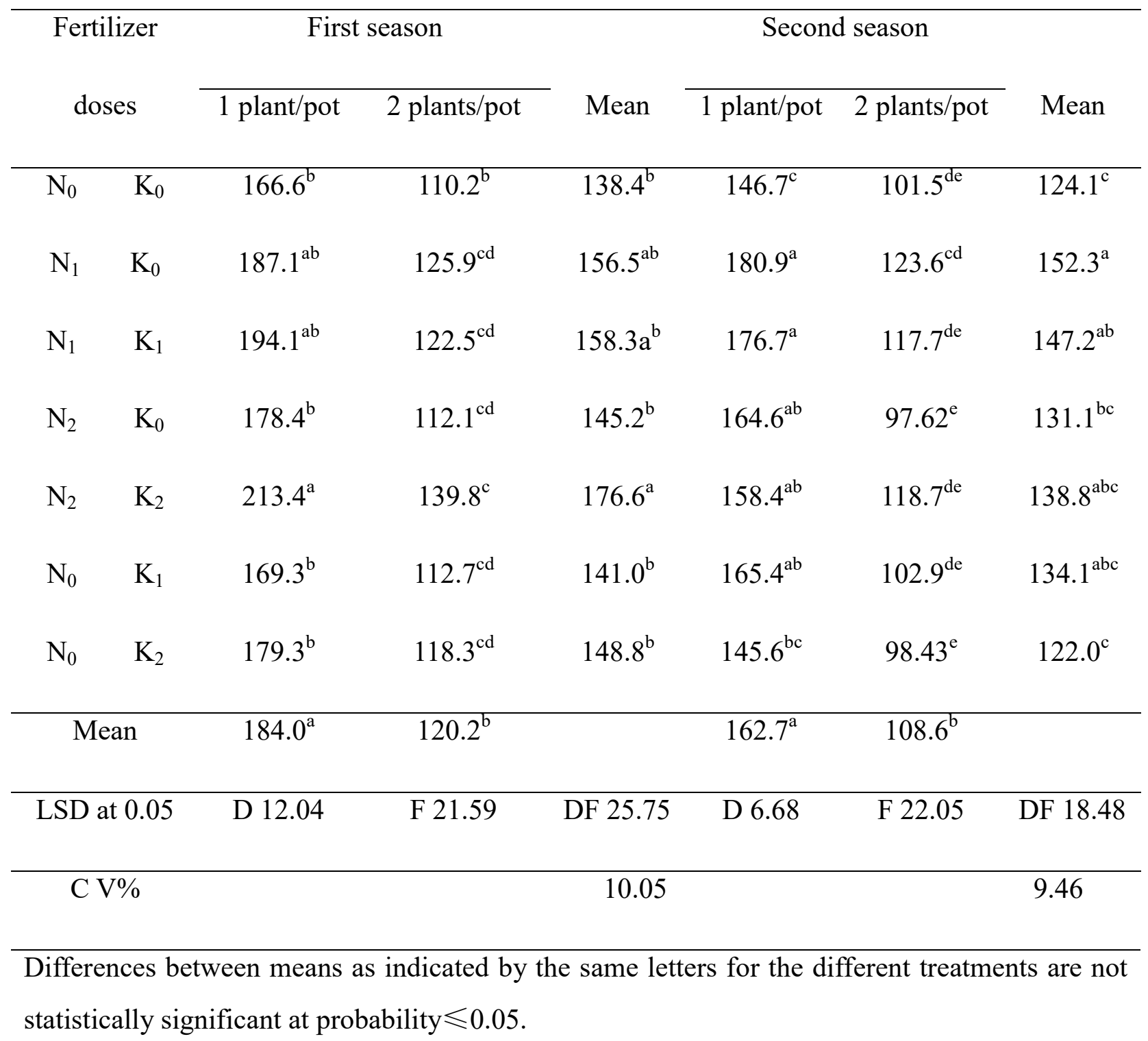




\subsection{Pod yield per hectare (ton $\left.\mathrm{ha}^{-1}\right)$}

Pods yield per hectare was calculated from the yield per plant multiplying by a number of plants per hectare; therefore the results followed the same pattern of significance and presented a different picture as green pod yield per plant (Table 6). Higher plant density $\left(\mathrm{D}_{2}\right)$ increased yield per unit area compared with lower density $\left(D_{1}\right)$. A full dose of nitrogen and potassium fertilizer in the first season $\left(\mathrm{N}_{2} \mathrm{~K}_{2}\right)$ and half dose of nitrogen in the second season $\left(\mathrm{N}_{1} \mathrm{~K}_{0}\right)$ had superior means in term of plant yield per hectare, followed by a plant treated with lower doses of nitrogen and potassium $\left(\mathrm{N}_{1} \mathrm{~K}_{1}\right)$ in both seasons, and plant receiving nitrogen without potassium $\left(\mathrm{N}_{1} \mathrm{~K}_{0}\right)$, in the first season. Plant grown without fertilizer $\left(\mathrm{N}_{0} \mathrm{~K}_{0}\right)$ or with potassium only $\left(\mathrm{N}_{0} \mathrm{~K}_{1} ; \mathrm{N}_{0} \mathrm{~K}_{2}\right)$ gave the lowest yield per hectare except the lower dose of potassium in the second season. Interaction between plant density and fertilizer had the same result due to doubling density. Higher density with all doses of fertilizers over yielded lower density. Dense plant $\left(D_{2}\right)$ received a full dose of nitrogen and potassium $\left(\mathrm{N}_{2} \mathrm{~K}_{2}\right)$ in the first season and the plant received a half dose of nitrogen only $\left(\mathrm{N}_{1} \mathrm{~K}_{0}\right)$ in the second season, gave the greatest means. The lower density $\left(\mathrm{D}_{1}\right)$ receiving no fertilizer $\left(\mathrm{N}_{0} \mathrm{~K}_{0}\right)$ in both seasons decreased yield. 
Table 6. Effect of plant density and dose nitrogen and potassium on pod yield per hectare (ton $\left.\mathrm{ha}^{-1}\right)$

\begin{tabular}{|c|c|c|c|c|c|c|c|}
\hline \multirow{2}{*}{\multicolumn{2}{|c|}{$\begin{array}{c}\text { Fertilizer } \\
\text { doses }\end{array}$}} & \multicolumn{2}{|c|}{ First season } & \multirow{3}{*}{$\begin{array}{l}\text { Mean } \\
20.81^{b}\end{array}$} & \multicolumn{2}{|c|}{ Second season } & \multirow{3}{*}{$\begin{array}{l}\text { Mean } \\
18.73^{\mathrm{c}}\end{array}$} \\
\hline & & \multirow{2}{*}{$\begin{array}{c}1 \text { plant/pot } \\
18.00^{\mathrm{e}}\end{array}$} & \multirow{2}{*}{$\begin{array}{c}2 \text { plants/pot } \\
23.62^{\mathrm{bc}}\end{array}$} & & \multirow{2}{*}{$\begin{array}{c}\text { plant/pot } \\
15.62^{\mathrm{f}}\end{array}$} & \multirow{2}{*}{$\begin{array}{c}2 \text { plants/pot } \\
21.75^{\mathrm{bc}}\end{array}$} & \\
\hline $\mathrm{N}_{0}$ & $\mathrm{~K}_{0}$ & & & & & & \\
\hline $\mathrm{N}_{1}$ & $\mathrm{~K}_{0}$ & $20.04^{\text {cde }}$ & $26.64^{\mathrm{ab}}$ & $23.34^{\mathrm{ab}}$ & $19.38^{\text {cdef }}$ & $26.50^{\mathrm{a}}$ & $22.94^{\mathrm{a}}$ \\
\hline $\mathrm{N}_{1}$ & $\mathrm{~K}_{1}$ & $20.80^{\text {cde }}$ & $26.04^{\mathrm{ab}}$ & $23.42^{\mathrm{ab}}$ & $18.93^{\text {cdef }}$ & $25.22^{\mathrm{ab}}$ & $22.08^{\mathrm{ab}}$ \\
\hline $\mathrm{N}_{2}$ & $\mathrm{~K}_{0}$ & $20.78^{\text {cde }}$ & $24.01^{\mathrm{bc}}$ & $22.40^{\mathrm{b}}$ & $17.64^{\mathrm{def}}$ & $20.92^{\text {cde }}$ & $19.28^{\mathrm{bc}}$ \\
\hline $\mathrm{N}_{2}$ & $\mathrm{~K}_{2}$ & $22.86^{\mathrm{bcd}}$ & $29.96^{\mathrm{a}}$ & $26.41^{\mathrm{a}}$ & $17.03^{\mathrm{ef}}$ & $25.42^{\mathrm{ab}}$ & $21.23^{\mathrm{abc}}$ \\
\hline $\mathrm{N}_{0}$ & $\mathrm{~K}_{1}$ & $18.13^{\mathrm{e}}$ & $24.15^{\mathrm{bc}}$ & $21.14^{\mathrm{b}}$ & $17.72^{\text {def }}$ & $22.05^{b c}$ & $19.89^{\mathrm{abc}}$ \\
\hline $\mathrm{N}_{0}$ & $\mathrm{~K}_{2}$ & $19.20^{\mathrm{de}}$ & $25.34^{\mathrm{b}}$ & $22.27^{b}$ & $15.60^{\mathrm{f}}$ & $21.08^{\mathrm{cd}}$ & $18.34^{\mathrm{c}}$ \\
\hline \multicolumn{2}{|c|}{ Mean } & $19.97^{b}$ & $25.68^{\mathrm{a}}$ & & $17.43^{b}$ & $23.28^{\mathrm{a}}$ & \\
\hline \multirow{2}{*}{\multicolumn{2}{|c|}{ LSD at 0.05}} & & & DF & & & $\mathrm{DF}$ \\
\hline & & D 2.35 & F 3.15 & 3.76 & D 2.05 & F 2.97 & 3.54 \\
\hline \multicolumn{2}{|c|}{ C V\% } & & & 9.78 & & & 10.32 \\
\hline
\end{tabular}

Differences between means as indicated by the same letters for the different treatments are not statistically significant at probability $\leqslant 0.05$.

\section{DISCUSSION}

The results of this experiment showed that the plant density and fertilizer doses had no effect on the number of branches per plant. This is in agreement with the results of Elhag and Hussein, (2014) who reported that there was no significant effect on the number of branches due to the number of plants per hole. Nutrient availability led to increase in plant dry weight. In both seasons lower plant density and higher dose of nitrogen and potassium in addition to lower nitrogen dose with potassium or without potassium and their interaction increased plant 
dry weight, resulting in an increasing in the number of pods and pods yield per plant. Similar result was obtained by Koli and Akashe (1995). They reported that increased dry weight in French beans with increasing in row spacing. Hatami et al., (2009) whe found that the nitrogen consumption increased plant dry weight resulting in increased plant yield. There was an inverse relationship between the density of plants and the number of pods per plant and a positive correlation between density and productivity of pods per unit area. Higher plant density produced fewer number of pods per plant, but the highest yield per unit area, due to increase the total number of plants per unit area, while the pod fresh weight was not affected (Figure 1). These results are in accordance with that of Elhag and Hussein, (2014) who found positive effects due to increase plant density. Alghamdi, (2002) reported that the number of plants per unit area seems to be more critical than the number of pods per planting influencing yield per unit area. Additionally, the application of nitrogen fertilizer at a higher or lower dose increased plant yield. This result is in close conformity with the findings of Moniruzzaman et al., (2009) recorded that the maximum number of green pods per plant with the lower plant density at the highest nitrogen level while, Srinivas and Naik, (1990); and Mtaita and Mutetwa, (2014) recorded the maximum pod yield of French bean at two higher doses of nitrogen. The application of potassium fertilizer without nitrogen had no effect on vegetative growth and yield parameters. This finding agrees with Ghallab et al., (2014) found that the highest total green pod yields was obtained by application of both nitrogen and potassium. However, a potassium fertilizer (alone) and untreated plants gave the lowest green pods. Seedy vegetables such as Pea and Bean absorbed less amount of potassium from the soil about $35 \mathrm{Kg} \mathrm{fed}^{-1}$ while, leafy vegetables absorbed more quantity of potassium about $160 \mathrm{Kg}$ fed $^{-1}$ (Hassan, 1997).

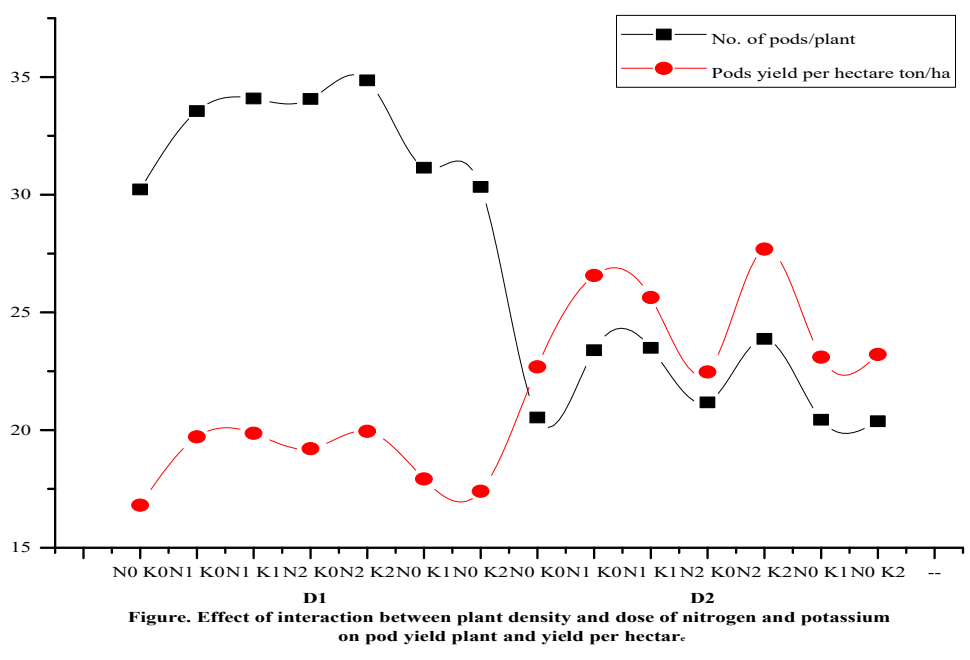




\section{CONCLUSION}

From the above discussion, it could be concluded that the bean plant should be cultivated in the soil of Blida state and the areas of the similar soils at the plant density of two plants per pot (214290 plants per hectare) with application of fertilizer dose spatially nitrogen in lower 0.46 or higher dose $0.92 \mathrm{~g} /$ pot (98.57 or $197.14 \mathrm{Kg}$ urea/ha) while, the individual application of potassium fertilizer had a limited effect on pod fresh weight in the first season.

\section{ACKNOWLEDGEMENTS}

I would like to thank the technical staff in the Laboratory of vegetable biotechnologies production for their support, intellectual and handwork and Dr: Mohamed Osman, Omar Elzubair Pof: Snousi Sid-Ahmed. Ministry of Higher Education and Scientific Research (Republic of Sudan) and Ministry of Higher Education and Scientific Research (Republic of Algeria) for the scholarship.

\section{REFERENCES}

[1] Alghamdi S.S. Effect of salinity on germination and seedling growth of selected genotypes of faba bean (Vicia faba L.). Alex. Sci. Exch., 2002, 23(4), 409-420.

[2] Beg M.Z and Sohrab A. Effect of potassium on Moong Bean. Indian. J. L. Sci., 2012, $1(2), 109-114$.

[3] Elhag A.Z and Hussein A.M. Effects of Sowing Date and Plant Population on Snap Bean (Phaseolus vulgaris L.) Growth and Pod Yield in Khartoum State. Universal. J. Agri. Res., 2014, 2(3), 115-118.

[4] Ghallab M.M, Marguerite A.R, Wahba B.S and Zaki A.Y. Impact of different types of fertilizers to reduce the population density of the sap sucking pests to bean plants. Egypt. Acad. J. Biolog. Sci., 2014, 7(2), 1-8.

[5] Hassan A.A. Principles of vegetable physiology. $1^{\text {st }}$ ed In: Nutrients elements and their effects on vegetable plants. Aldoge, Cairo, Egypt. Academic library1997, pp. 334.

[6] Hatami H, Aynehband A, Azizi M.S and khodabandeh M. Effect of nitrogen fertilizer on growth and yield of soybean in North Khorasan. Electr. J. crop. Prod., 2009, 2(2), 25- 42.

[7] Hirel B.J, Gouis B, Ney A and Gallais F. The challenge of improving nitrogen use efficiency in crop plants: towards a more central role for genetic variability and quantitative genetics within integrated approaches. J. Exp. Bot., 2007, 58(9), 2369-2387.

[8] Koli B.D and Akashe V.B. Dry matter production of French bean variety Waghya as 
influenced by row spacing, plant densities and nitrogen levels. Curr. Res., 1995, 20, 209-211.

[9] Mfilinge A, Kevin M and Patrick A.N. Effects of rhizobium inoculation and supplementation with $\mathrm{P}$ and $\mathrm{K}$, on growth, leaf chlorophyll content and nitrogen fixation of Bush bean varieties. Amer. J. Res. Communication., 2014 2(10) 49-87.

[10] Monfreda C, Navin R and Jonathan A.F. Farming the planet: 2. Geographic distribution of crop areas, yields, physiological types, and net primary production in the year 2000. Glob. biogeochem. cycle., 2008, 22(1), 1022-1041.

[11] Moniruzzaman M, Halim G.M and Firoz Z.A. Performances of French bean as influenced by plant density and nitrogen application. Bangladesh. J. Agril. Res., 2009, 34(1) 105-111.

[12] Mtaita T and Mutetwa M. Effect of plant density and planting arrangement in Green bean seed production. J. Glob. Innov. Agric. Soc Sci., 2014, 2(4), 152-157.

[13] Srinivas K and Naik, L. B. Growth yield and nitrogen uptake in vegetable French bean (Phaseolus vulgaris L.) as influenced by nitrogen and phosphorous fertilization. Haryana. J. Hortc. Sci., 1990, 19(1-2), 160-167.

[14] Vorob V.A. Effective inoculation of leguminous plants in relation to provision of phosphorus and potassium and dependence on rhizosphere temperature. Agrokhimiya., 2000, 2(222), 42-44.

\section{How to cite this article:}

Hussein A, Benmoussa M, Abbad M. Effect of population density and dose of nitrogen and potassium fertilizers on performance of green bean (phaseolus vulgaris). J. Fundam. Appl. Sci., 2018, 10(1), 46-58. 